\title{
IDENTIFIKASI KESULITAN BELAJAR KIMIA SISWA SMA NEGERI 1 NARMADA SELAMA PANDEMI COVID-19
}

\author{
Widya Hilalia Iswara ${ }^{1^{*}}$, Muntari ${ }^{2}$, Rahmawati ${ }^{3}$ I Nyoman Loka ${ }^{4}$ \\ 1234 Program Studi Pendidikan Kimia, Universitas Mataram. Jalan Majapahit No. 62 \\ Mataram, NTB 83112, Indonesia. \\ * Coressponding Author. E-mail: Widya4hilalia@gmail.com
}

Received: 30 Mei 2021

Accepted: 30 November 2021 Published: 30 November 2021

doi: 10.29303/cep.v4i3.2694

\begin{abstract}
Abstrak
Penelitian ini bertujuan untuk mengetahui (1) tingkat kesulitan belajar kimia siswa, (2) faktorfaktor yang menyebabkan kesulitan belajar kimia siswa, (3) hubungan antara faktor-faktor kesulitan belajar kimia siswa dengan hasil belajar kimia siswa. Jenis penelitian ini merupakan penelitian deskriptif dengan pendekatan kuantitatif. Populasi penelitian ini adalah siswa-siswi kelas XII MIPA tahun ajaran 2020/2021 yang berjumlah 196 orang dan diambil 130 orang sebagai sampel. Teknik pengumpulan data menggunakan soal tes, angket tertutup dan dokumentasi. Analisis data menggunakan analisis data perhitungan rata-rata (mean) skor dengan bantuan Microsoft Excel 2016 dan analisis korelasi. Hasil penelitian menunjukkan bahwa (1) tingkat kesulitan belajar kimia siswa paling tinggi terdapat pada indikator ke-3 (menghitung tekanan uap larutan elektrolit) pada soal nomor 4 sebesar 71,58\% dengan kategori tinggi (2) faktor penyebab kesulitan belajar siswa ditinjau dari faktor internal yaitu faktor minat dengan sebesar $69,23 \%$, dan faktor motivasi sebesar $51,53 \%$, sedangkan pada faktor eksternal yaitu faktor keluarga sebesar 45,39\%, faktor sekolah 42,30\%, faktor masyarakat 49,23\% dan faktor materi kimia sebesar $60,77 \%$. (3) terdapat hubungan antara faktor-faktor kesulitan belajar kimia siswa dengan hasil belajar kimia siswa dengan koefisien korelasi 0,357.
\end{abstract}

Kata Kunci: Kesulitan belajar, Identifikasi, Kimia

\section{Identification of Difficulties Learning Chemistry for Class XII MIPA Student's of SMA Negeri 1 Narmada}

\begin{abstract}
This research aims to determine (1) the level of difficulty in learning chemistry of students, (2) the factors that cause difficulty in learning chemistry of students, (3) the correlation between the factors of difficulty in learning chemistry with students learning outcomes chemistry. This type of research is a descriptive study with a quantitative approach. The population of this study were 196 students of class XII MIPA for the academic year 2020/2021 and 130 people were taken as samples. Data collection techniques using test questions, closed questionnaires and documentation. Data analysis used data analysis to calculate the average (mean) score with the help of Microsoft Excel 2016 and correlation analysis. The results showed that (1) the highest level of students difficulty in learning chemistry was found in the 3rd indicator (calculating the vapor pressure of the electrolyte solution) in question number 4 of $71.58 \%$ with a high category (2) the factors causing student learning difficulties in terms of factors internal factors, namely the interest factor of $69.23 \%$, and the motivation factor of $51.53 \%$, while the external factors were family factors of $45.39 \%$, school factors $42.30 \%$, community factors $49.23 \%$ and chemical factors. amounted to $60.77 \%$. (3) there is a correlation between the factors of student learning difficulties with chemistry learning outcomes of students with a correlation coefficient of 0.357.
\end{abstract}

Keywords: Learning difficulties, Identification, Chemistry 


\section{Chemistry Education Practice, 4 (3), 2021 - 243}

Iswara, Muntari, Rahmawati, Loka

\section{PENDAHULUAN}

Pendidikan sangat penting bagi kehidupan manusia karena melalui pendidikan manusia dapat mengembangkan dirinya, sehingga mampu menghadapi segala perubahan dan permasalahan dengan sikap terbuka serta pendekatan-pendekatan yang kreatif tanpa harus kehilangan identitas dirinya. Secara umum tujuan dari pendidikan adalah untuk meningkatkan kecerdasan bangsa, melalui peningkatan pemahaman terhadap materi yang diajarkan (Dinatha, 2017).

Setiap lembaga pendidikan menginginkan proses belajar mengajar yang ideal, baik dari segi kualitas maupun kuantitas. Akan tetapi realitanya tidak semua pembelajaran yang terjadi disekolah mencapai tingkat yang ideal, terkadang dalam proses pembelajaran terdapat beberapa permasalahan, seperti kesulitan belajar yang sering dialami oleh siswa. Kesulitan belajar merupakan kondisi saat siswa mengalami hambatan-hambatan tertentu untuk mengikuti proses pembelajaran dan mencapai hasil belajar secara optimal(Djamarah, 2002).

Kimia menjadi salah satu mata pelajaran yang kurang disukai di kalangan siswa, karena dalam sains terutama kimia dipelajari hal-hal yang abstrak (Ristiyani, 2016). Ilmu kimia adalah ilmu rekayasa materi, yang materinya terdiri dari konsep-konsep seperti atom, molekul, electron dan konsep-konsep berupa azas, hukum, persamaan reaksi, serta operasi matematika. Akibatnya adalah siswa sering mengalami: kesulitan dalam membaca dan memahami kalimat atau istilah, kesulitan dengan angka-angka, dan kesulitan memahami konsep-konsep kimia sehingga menimbulkan kejengkelan, kebosanan, dan sikap masa bodoh (Haris, 2008).

Penyebab siswa mengalami kesulitan dalam belajar kimia, adalah: kurangnya minat dan perhatian siswa pada saat proses pembelajaran berlangsung, kurangnya kesiapan siswa dalam menerima konsep baru, kurangnya penekanan pada konsep-konsep prasyarat yangpenting, penanaman konsep yang kurang mendalam, strategi belajar, dan kurangnya variasi latihan soal (Yakina, 2017). Haris dkk (2019) menemukan beberapa faktor yang menyebabkan siswa mengalami kesulitan belajar kimia, di antaranya guru kurang menguasai materi, tidak menggunakan media pembelajaran, dan guru tidak menerapkan berbagai pembelajaran inovatif yang menuntut siswa aktif.

Saat ini negara kita sedang dilanda musibah besar, yaitu adanya wabahatau virus yang menyerang manusia di seluruh dunia yaitu dikenal dengan covid-19, dimana wabah atau virus ini menyerang siapapun, sehingga menyebabkan negara kita Indonesia juga harus sangat waspada, dan menetapkan untuk melakukan kegiatan di rumah saja, serta harus melakukan social distancing untuk menjagaagar memperlambat penyebaran covid-19. Menurut WHO (2019) Coronavirus merupakan keluarga besar virus yang menyebabkan penyakit pada manusia dan hewan (Cahyati, 2020).

Oleh karena itu adanya instruksi pencegahan penyebaran virus corona agar bekerja dari rumah (BDR) secara online untuk siswa dan guru. BDR merupakan sebuah proses pembelajaran yang dilakukan oleh siswa dan guru di rumah masing-masing. Dalam pembelajaran ini, guru tidak hadir dalam satu ruangan dengan murid tetapi berlangsung di tempat yang berbeda. Pembelajaran jarak jauh dilakukan dengan bantuan media berupa perangkat elektronik seperti laptop, HP android yang terhubung melalui jaringan internet. Pembelajaran ini dinamakan pembelajaran daring/online (Prasetyaningtyaas, 2020).

Berdasarkan hasil observasi di SMA Negeri 1 Narmada, terdapat beberapa permasalahan yang terjadi dalam proses belajar mengajar secara daring/online diantaranya hasil belajar siswa yang tidak mencapai nilai KKM. Ketika dilakukan penilaian akhir semester (PAS) kelas XI IPA pada materi kimia yang dilaksanakan secara daring dalam bentuk tugas pada bulan Juni 2020 diperoleh 19\% tuntas belajar dan sebanyak $81 \%$ tidak tuntas belajar, sedangkan nilai KKM dari sekolah adalah 75 . Timbulnya permasalahan tersebut mendorong dilakukannya penelitian untuk mengetahui seberapa besar faktor penyebab kesulitan siswa dalam mengikuti mata pelajaran kimia agar dapat diperoleh solusi yang tepat untuk siswa yang mengalami kesulitan belajar.

Berdasarkan uraian di atas, identifikasi kesulitan belajar siswa pada materi kimia perlu dilakukan untuk mengetahui tingkat kesulitan yang dialami siswa serta faktor-faktor yang mempengarui kesulitan siswa dalam belajar kimia. Oleh karena itu, peneliti tertarik melakukan penelitian yang berjudul "Identifikasi Kesulitan Belajar Kimia Siswa Kelas XII SMA Negeri 1 Narmada".

\section{METODE}

Penelitian ini menggunakan jenis penelitian deskriptif dengan pendekatan kuantitatif. Menurut Sugiyono (2018), penelitian deskriptif digunakan untuk menganalisis data dengan cara mendeskripsikan atau 


\section{Chemistry Education Practice, 4 (3), 2021 - 244}

Iswara, Muntari, Rahmawati, Loka

menggambarkan data yang telah terkumpul sebagaimana adanya. Penelitian kuantitatif adalah penelitian yang menggunakan angka, seperti misalnya penafsiran terhadap data tersebut, serta penampilan dari hasilnya (Arikunto, 2016). Variabel bebas dalam penelitian ini adalah faktorfaktor kesulitan belajar kimia. Sedangkan variabel bebasnya adalah hasil belajar kimia.

Adapun yang menjadi populasi subjek dalam penelitian ini adalah siswa kelas XII MIA SMAN 1 Narmada yang berjumlah sebanyak 196 orang yang terdiri dari 6 kelas. Teknik penentuan sampel penelitian menggunakan teknik Simple Random Sampling. Untuk teknik pengambilan sampel siswa ditiap-tiap kelas menggunakan rumus Isaac dan Michael dengan taraf kesalahan $5 \%$.

Instrumen penelitian yang digunakan pada penelitian ini yaitu soal tes uraian dan lembar angket atau kuisioner dengan skala Likert. Instrumen penelitian ini telah divalidasi oleh dua dosen pendidikan kimia dan satu guru kimia SMAN 1 Narmada. Instrumen penelitian ini diuji realiabilitas menggunakan rumus alfa Crombach dengan bantuan Microsoft Exel 2016. Hasil yang didapatkan dari perhitungan reliabilitas yaitu, diperoleh nilai koefisien reliabilitas angket kesulitan belajar kimia r-hitung sebesar 0,812 dengan kategori sangat tinggi. Sedangkan nilai koefisien reliabilitas soal tes kesulitan belajar kimia diperoleh r-hitung sebesar 0,742 dengan kategori tinggi.

\section{Analisis Soal Tes}

Skor yang diperoleh siswa adalah banyaknya butir soal yang dijawab benar. Dengan menggunakan rumus penskoran sebagai berikut:

$$
\text { Nilai perolehan }=\frac{\text { Skor yang dicapai }}{\text { Skor maksimal }} \times 100
$$

Setelah dilakukan penskoran terhadap data tes tersebut, persentase kesulitan belajar siswa tiap butir soal dapat diukur dengan menggunakan perhitungan persentase untuk mengetahui seberapa besar tingkat kesulitan belajar yang dialami siswa dengan rumus menurut Sriningsih (Sakti, 2018) sebagai berikut:

$$
\begin{aligned}
& \mathrm{P}==\frac{\text { Skor yang dicapai }}{\text { Skor maksimal }} \times 100 \% \\
& \% \mathrm{~K}=100 \%-\mathrm{P}
\end{aligned}
$$

Dengan $\mathrm{P}$ adalah persentase siswa yang tidak mengalami kesulitan pada tiap butir soal dan $\% \mathrm{~K}$ adalah persentase kesulitan yang dialami siswa pada tiap butir soal.

\section{Analisis Angket}

Analisis deskiptif yang digunakan dalam penelitian ini adalah melalui perhitungan rata-rata (mean), median, modus, skor tertinggi (maks), skor terendah (min), simpangan baku (SD) dan frekuensi dari data angket faktor-faktor kesulitan belajar. Berdasarkan perhitungan tersebut kemudian membuat kategori skor sebagai pedoman untuk memberikan intepretasi pada masing-masing indikator yaitu:

$\mathrm{Mi}=1 / 2($ Skor ideal tertinggi + Skor ideal terendah $)$ $\mathrm{SDi}=1 / 6$ (Skor ideal tertinggi - Skor ideal terendah) Skor ideal tertinggi $=$ skor maksimum $\mathrm{x}$ jumlah item Skor ideal terendah $=$ skor minimum $\mathrm{x}$ jumlah item Keterangan:

Mi $=$ Mean (Nilai rata-rata Ideal)

Sdi $=$ Standar Deviasi Ideal

(Azwar, 2012)

\section{Uji Hipotesis}

Uji hipotesis yang digunakan pada penelitian ini adalah analisis Bivarat. Analisis bivariat digunakan untuk menguji hipotesis pertama dan kedua yaitu untuk menguji koefisien antara variabel bebas dengan variabel terikatnya. Untuk menguji arah hubungan antara variabel bebas dengan variabel terikat, rumus yang digunakan adalah korelasi product moment (Basyari, 2013).

\section{HASIL DAN PEMBAHASAN}

\section{Tingkat Kesulitan Belajar Kimia Siswa}

Siswa dikatakan mengalami kesulitan belajar jika hasil belajar yang diperoleh siswa tidak mencapai kriteria ketuntasan minimal (KKM) yang telah ditetapkan oleh pihak sekolah yaitu 75. Berdasarkan hasil rekapitulasi soal terdapat hanya $36(27,70 \%)$ siswa yang tuntas dan $94(72,30 \%)$ siswa tidak tuntas dari 130 siswa. Banyaknya siswa yang tidak tuntas menunjukkan bahwa siswa tersebut mengalami kesulitan belajar kimia yang dapat dilihat pada materi sifat koligatif larutan. Pada beberapa konsep materi sifat koligatif larutan yang ditunjukkan dapat dikuasai oleh seluruh siswa dan ada pula pada beberapa konsep tertentu sulit dikuasai sebagian besar siswa.

Tabel 1. Tingkat Kesulitan Belajar Siswa PerIndikator

\begin{tabular}{ccl}
\hline Indikator & Kesulitan (\%) & \multicolumn{1}{c}{ Kriteria } \\
\hline $\mathbf{1}$ & 43,14 & Cukup Tinggi \\
$\mathbf{2}$ & 34,23 & Rendah \\
$\mathbf{3}$ & 22,06 & Rendah \\
$\mathbf{4}$ & 71,58 & Tinggi \\
$\mathbf{5}$ & 40,70 & Cukup Tinggi \\
$\mathbf{6}$ & 14,91 & Sangat Rendah \\
$\mathbf{7}$ & 6,44 & Sangat Rendah \\
Rerata & 33,29 & Rendah \\
\hline
\end{tabular}




\section{Chemistry Education Practice, 4 (3), 2021 - 245}

Iswara, Muntari, Rahmawati, Loka

Berdasarkan analisis jawaban dari tes uraian, dapat diketahui bahwa siswa mengalami kesulitan belajar pada materi kimia yaitu salah satunya sifat koligatif larutan dengan kategori yang tinggi. Urutan kesulitan belajar siswa yang paling tinggi terdapat pada indikator ke-3 pada soal nomor 4 sebesar 71,58\% dengan kategori tinggi. Tingkat kesulitan yang kedua terdapat pada indikator ke-1 pada soal nomor 1 sebesar $43,13 \%$ dengan cukup tinggi. Tingkat kesulitan yang ketiga terdapat pada indikator ke-3 pada soal nomor 5 sebesar $40,01 \%$ dengan kategori cukup tinggi. Tingkat kesulitan yang keempat terdapat pada soal nomor 2 sebesar $34,23 \%$ dengan kategori rendah. Tingkat kesulitan yang kelima terdapat pada soal nomor 3 sebesar $22,06 \%$ dengan kategori rendah. Tingkat kesulitan yang keenam terdapat pada indikator ke-4 pada soal nomor 6 sebesar 14,91\% dengan kategori sangat rendah. Tingkat kesulitan yang ketujuh terdapat pada soal nomor 7 sebesar $6,44 \%$ dengan kategori sangat rendah.

Tabel 1 menunjukkan secara umum siswa mengalami kesulitan belajar kimia pada tingkat rendah $(33,29 \%)$. Pada indikator 1 yaitu, menganalisis contoh fenomena sifat koligatif larutan dalam kehidupan sehari-hari, data hasil penelitian diwakili oleh soal nomor 1. Pada soal nomor 1 ini kesulitan yang dialami siswa berada pada kategori cukup tinggi. Sebagian siswa dapat menjawab soal ini dengan benar. Berdasarkan data tes uraian siswa, diketahui bahwa siswa yang tidak bisa menjawabnya disebabkan oleh kemampuan mengingat contoh fenomena sifat koligatif dalam kehidupan sehari-hari yang rendah, sehingga siswa tidak dapat menjelaskan fenomena yang terjadi pada saat penjual es potong menaruh garam desekeliling es balok. Adapun sebagian siswa malah menjelaskan proses pembuatan es potong.

Pada indikator 2 yaitu, menghitung kenaikan titik didih dan penurunan titik beku larutan elektrolit dan nonelektolit, data hasil penelitian diwakili oleh soal nomor 2 dan 3. Pada soal nomor 2 kesulitan yang dialami siwa berada pada kategori rendah. Sebagian besar siswa dapat menjawab soal ini dengan benar. Berdasarkan data tes uraian siswa, diketahui bahwa siswa yang tidak bisa menjawabnya disebabkan oleh siswa mengalami kesulitan dalam membedakan rumus sifat koligatif larutan elektrolit dan nonelektrolit, dikarenakan siswa juga tidak tahu larutan $\mathrm{MgSO}_{4}$ merupakan larutan elektolit. Serta siswa kesulitan dalam menentukan mol melalui persamaan reaksi ionisasi $\mathrm{MgSO}_{4}$. Hal ini menyebabkan siswa keliru dalam menggunakan rumus yang tepat untuk menghitung derajat ionisasi dan titik beku larutan elektrolit. Sedangkan pada soal nomor 3 kesulitan yang dialami siswa berada pada kategori rendah. Sebagian besar siswa juga menjawab dengan benar dan untuk siswa yang menjawab salah dikarenakan salah dalam menghitung molaritas untuk larutan. Hal tersebut menyebabkan hasil perhitungan menjadi salah dan kurang tepat.

Pada indikator 3 yaitu, menghitung tekanan uap larutan elektrolit dan non elektrolit, data hasil penelitian diwakili oleh soal nomor 4 dan 5. Pada soal nomor 4 dan 5 persentase kesulitan yang dialami siwa berada pada kategori tinggi. Berdasarkan data hasil tes uraian, pada soal nomor 4 kesulitan yang dialami siswa adalah menentukan fraksi mol dan molalitas larutan $\mathrm{H}_{2} \mathrm{SO}_{4}$. Kesulitan siswa disebabkan oleh siswa tidak mengetahui rumus untuk menentukan molalitas dan fraksi mol, sehingga siswa keliru dalam menggunakan rumus yang tepat untuk menentukan molalitas dan fraksi mol larutan $\mathrm{H}_{2} \mathrm{SO}_{4}$. Hal tersebut menyebabkan penentuan tekanan uap pada larutan elektolit menjadi kurang tepat. Pada soal nomor 5 berdasarkan data hasil tes uraian, siswa yang salah menjawab mengalami kesulitan pada menentukan fraksi mol juga dan salah menggunakan rumus tekanan uap pada larutan nonelektolit. Sehingga hasil perhitungan untuk tekanan uap non elektrolit tidak tepat.

Pada indikator 4 yaitu, menghitung tekanan osmosis larutan elektrolit dan non elektrolit, data hasil penelitian diwakili oleh soal nomor 6 dan 7. Pada soal nomor 6 dan 7 persentase kesulitan yang dialami siwa berada pada kategori sangat rendah. Berdasarkan data hasil tes uraian, pada soal nomor 6 dan 7 hampir semua siswa menjawab dengan benar, ada beberapa saja yang menjawab salah. Siswa yang menjawab salah tersebut dikarenakan siswa tidak bisa menentukan larutan yang digunakan apakah itu larutan elektolit atau nonelektrolit. Sehingga siswa keliru dalam menentukan rumus tekanan osmosisnya. Sedangkan pada soal nomor 7 siswa yang menjawab salah sebagian besar tidak menjawabnya sama sekali atau tidak mengerjakan soal tersebut.

\section{Faktor yang Mempengaruhi Kesulitan Belajar}

Dalam pengolahan data, peneliti menggunakan bantuan Microsoft Office Excel 2010. Deskripsi data yang digunakan meliputi cakupan mean (M), median (Me), skor terendah, skor tertinggi, standar deviasi (SD), histogram, dan tabel kecendrungan masing-masing indikator yang diperoleh dan perhitungan deskripsi data. Adapun cara untuk mengetahui 


\section{Chemistry Education Practice, 4 (3), 2021 - 246}

Iswara, Muntari, Rahmawati, Loka

secara lengkap mengenai deskripsi data dan analisis data dalam perhitungan data, dilihat sebagai berikut:

\section{1) Faktor Internal}

Faktor internal yang diamati dalam penelitian ini terdiri dari lima aspek yaitu minat, motivasi, dan kesehatan. Berikut grafik data dari ketiga aspek tersebut, sebagai berikut:

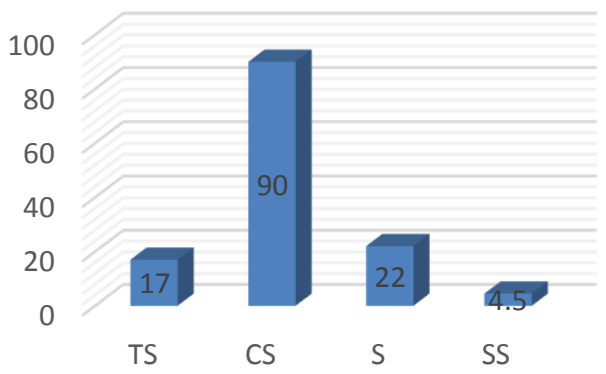

Gambar 1. Grafik data faktor minat belajar siswa

Berdasarkan grafik diatas, faktor minat tergolong cukup sulit, dimana siswa mendapat persentase sebesar $69,23 \%$ adalah sebanyak 90 siswa yang dikategorikan cukup sulit. Adapun skor mean faktor minat adalah 8,27 dan terletak pada skor rentang 9,5-9,75 menunjukkan bahwa faktor minat siswa termsuk cukup sulit.

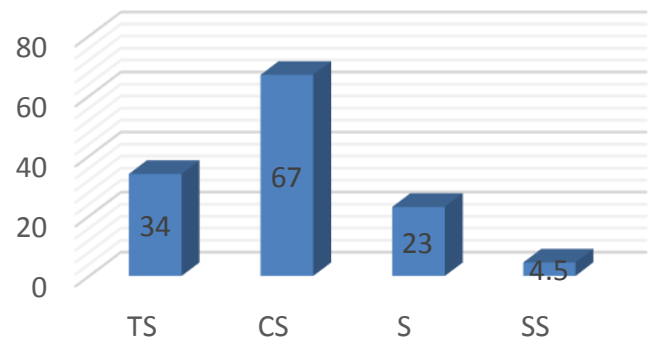

Gambar 2. Grafik data faktor motivasi belajar siswa

Berdasarkan data grafik diatas, faktor motivasi tergolong cukup sulit, dimana siswa mendapat persentase sebesar $51,53 \%$ adalah sebanyak 67 siswa yang dikategorikan cukup sulit. Adapun skor mean faktor minat adalah 6,04 dan terletak pada skor rentang 5-6,5 menunjukkan bahwa faktor motivasi siswa termsuk cukup sulit.

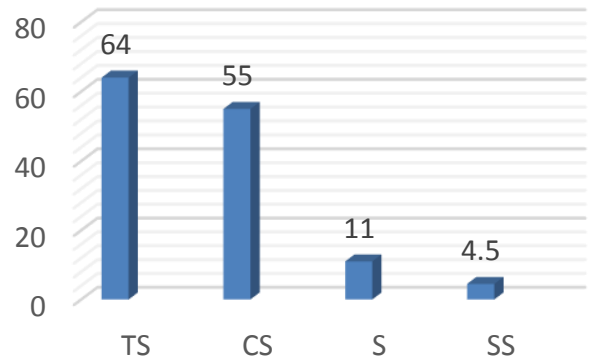

Gambar 3. Grafik data faktor kesehatan siswa
Berdasarkan grafik diatas, faktor motivasi tergolong tidak sulit, dimana siswa mendapat persentase sebesar $49,23 \%$ adalah sebanyak 64 siswa yang dikategorikan tidak sulit.Adapun skor mean faktor kesehatan adalah 13,22 dan terletak pada skor rentang >13 menunjukkan bahwa faktor kesehatan siswa termsuk tidak sulit.

\section{2) Faktor Eksternal}

Faktor eksternal yang diamati dalam penelitian ini terdiri dari empat aspek yaitu sekolah, materi kimia, lingkungan keluarga dan masyarakat. Berikut grafik data dari keempat aspek tersebut, sebagai berikut:

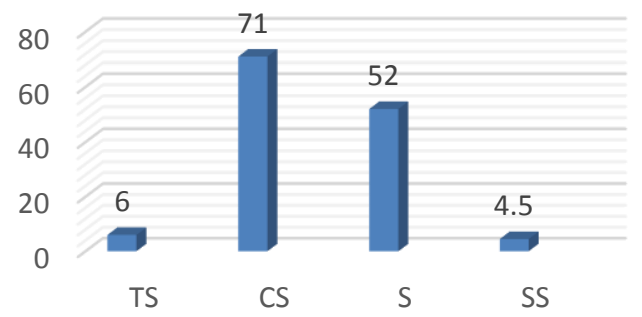

Gambar 4. Grafik data faktor sekolah

Berdasarkan grafik, faktor sekolah siswa tergolong cukup sulit, dimana ditunjukan sebanyak 71 siswa atau dengan presentase sebesar 42,30\% pada kategori cukup sulit. Adapun skor mean faktor sekolah menunjukan 10,88. Dengan rentang skor $10 \mathrm{~s} / \mathrm{d} 13$ berarti faktor lingkungan sekolah siswa dapat cukup mempersulit proses belajar siswa.

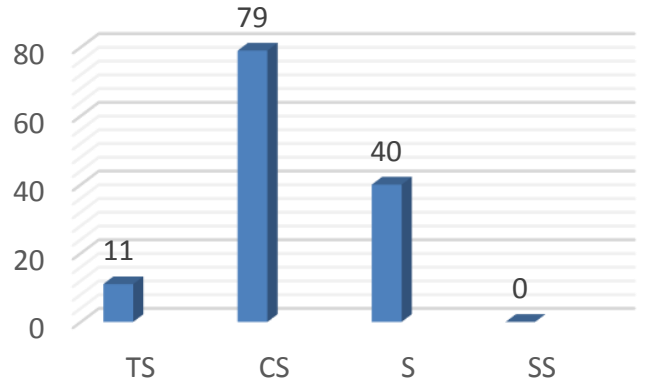

Gambar 5. Grafik data faktor materi

Berdasarkan data grafik, faktor materi kimia tergolong cukup sulit, dimana ditunjukan sebanyak 79 siswa atau dengan presentase sebesar $60,77 \%$ pada kategori cukup sulit. Adapun skor mean faktor sekolah menunjukan 2,76. Dengan rentang skor 2,5 s/d 3,25 berarti faktor materi kimia dapat cukup mempersulit proses belajar siswa. 


\title{
Chemistry Education Practice, 4 (3), 2021 - 247
}

\author{
Iswara, Muntari, Rahmawati, Loka
}

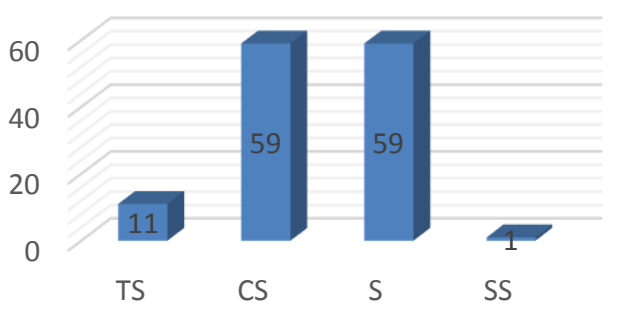

Gambar 6. Grafik data faktor keluarga

Berdasarkan data grafik, faktor keluarga tergolong sulit, dimana ditunjukan sebanyak 61 siswa atau dengan presentase sebesar $46,92 \%$ pada kategori sulit dan cukup sulit. Adapun skor mean faktor sekolah menunjukan 10,76. Dengan rentang skor $10 \mathrm{~s} / \mathrm{d} 13$ berarti faktor keluarga dapat cukup mempersulit proses belajar siswa.

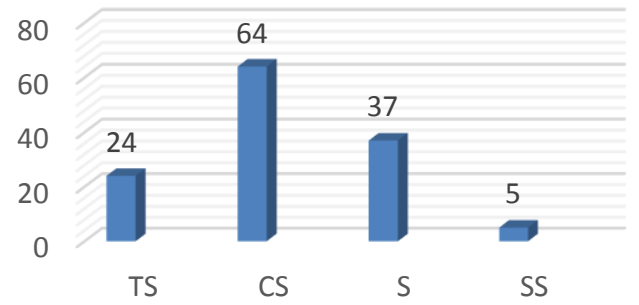

Gambar 7. Grafik data faktor masyarakat

Berdasarkan data grafik faktor masyarakat tergolong cukup sulit, dimana ditunjukan sebanyak 64 siswa atau dengan presentase sebesar 49,23\% pada kategori cukup sulit. Adapun skor mean faktor sekolah menunjukan 8,3. Dengan rentang skor 7,5 s/d 9,75 berarti faktor materi kimia dapat cukup mempersulit proses belajar siswa.

Berdasarkan hasil penelitian minat siswa tergolong pada kategori cukup sulit, dengan minat sebanyak 16,92\% dengan 22 siswa dalam kategori sulit. Hal ini disebabkan oleh hambatan-hambatan lain yang tidak sesuai dengan tujuan pembelajaran misalnya bahan pelajaran yang disajikan, media pembelajaran, strategi pembelajaran yang digunakan guru dan lain sebagainya. Hal tersebut sesuai dengan pendapat Slameto (2015) bahwa minat yang besar pengaruhnya terhadap belajar, karena bila bahan pelajaran yang dipelajarinya tidak sesuai minat siswa, siswa tidak akan belajar dengan sebaik-baiknya.

Hasil analisis data yang mengkaji tentang faktor motivasi menunjukkan bahwa faktor motivasi memiliki kecendrungan cukup sulit dengan persentase skor $17,70 \%$ dengan sebanyak 23 siswa dalam kategori rendah. Dalam menentukan motivasi dapat disadari atau tidak bahwa untuk mencapai tujuan perlu berbuat, sedangkan yang menjadi penyebab melakukan sesuatu adalah motivasi itu sendiri sebagai daya penggerak atau pendorongnya. Motivasi di dalam kegiatan belajar merupakan kekuatan yang dapat menjadi tenaga pendorong bagi siswa untuk mendayagunakan potensi-potensi yang ada pada dirinya dan potensi di luar dirinya utnuk mewujudkan tujuan belajar (Aunurrahman, 2014).

Adapun hasil penelitian faktor kesehatan dapat dikatakan bahwa dari aspek kondisi fisik siswa, serta kondisi penglihatan dan pendengaran siswa kelas XII MIA SMAN 1 Narmada dalam keadaan baik dan siswa tidak merasa kesulitan, dengan persentase $8,46 \%$ dengan 11 siswa dalam kategori rendah. Baiknya berfungsi pancaindera merupakan syarat dapatnya belajar itu berlansung dengan baik (Suryabrata, 2011:236). Selain itu, hal tersebut sependapat dengan Slameto (2015) bahwa proses belajar akan terganggu jika kesehatan seseorang terganggu. Jadi pentingnya siswa selalu menjaga kesehatan tubuh dan alat inderanya.

Sedangkan persentase hasil penelitian untuk faktor eksternal penyebab kesulitan belajar diketahui faktor sekolah dapat dikatakan kurang mendukung aktivitas belajar mengajar daring/online, dengan skor persentase kategori cukup sulit sebesar 40,76\% dengan 52 siswa dalam kategori sulit. Hal ini disebabkan oleh media pembelajaran online yang kurang diberikan oleh sekolah seperti kuota untuk akses internet dan aplikasi belajar online. Selain itu Slameto (2015) berpendapat bahwa alat pembelajaran erat hubungannya dengan cara belajar siswa, karena alat yang dipakai guru pada waktu belajar dipakai pula oleh siswa untuk menerima bahan yang diajarkan itu. Sehingga apabila alat belajar yang kurang mendukung proses belajar mengajar dapat menyebabkan siswa sulit dapat menerima materi pelajaran.

Selanjutnya faktor materi kimia yang dipelajari oleh siswa, yang terdiri dari pemahaman konsep dari materi kimia serta pemahaman terhadap karakteristik materi. Hasil analisis didapatkan termasuk dalam kategori sulit dengan skor persentase $30,77 \%$ dengan banyak 40 siswa merasa kesulitan dengan pemahaman konsep materi kimia. Pembelajaran kimia berfungsi untuk mengembangkan kemampuan menghitung, mengukur, dan menggunakan rumus kimia yang diperlukan dalam kehidupan sehari-hari. Menurut Arifin, dalam Rumansyah (2004) kebanyakan konsepkonsep dalam ilmu kimia maupun materi kimia secara keseluruhan merupakan konsep atau 


\section{Chemistry Education Practice, 4 (3), 2021 - 248}

Iswara, Muntari, Rahmawati, Loka

materi bersifat abstrak dan kompleks, sehingga siswa dituntut untuk memahami konsep tersebut secara benar dan mendalam.

Adapun hasil penelitian faktor keluarga sebesar 45,39\% yaitu sebanyak 59 siswa merasa kesulitan dalam belajar, begitu juga dengan siswa yang merasa cukup sulit. Dimana faktor keluarga termasuk kategori cukup mempersulit belajar siswa. Lingkungan keluarga merupakan salah satu faktor yang mempengaruhi siswa dalam belajar. Hal ini meliputi yang diberikan orang tua terhadap anaknya dalam mendukung kegiatan kegiatan belajar di rumah, kondisi ekonomi keluarga dalam memenuhi kebutuhan sekolah anak seperti alat belajar pada saat belajar online/daring, serta suasana rumah saat siswa belajar daring/online belajar. Menurut Slameto (2015) anak pada saat belajar perlu dorongan dan perhatian orang tua, bila anak sedang belajar jangan diganggu dengan tugas-tugas di rumah.

Sedangkan analisis hasil penelitian mengenai faktor lingkungan masyarakat tergolong dalam kategori cukup mempersulit dengan skor persentase 28,46\% dengan 37 siswa dalam kategori sulit. Lingkungan masyarakat yang baik akan menumbuhkan kebiasaan yang baik pula dalam kehidupannya. Masyarakat merupakan faktor ektern yang juga berpengaruh terhadap belajar siswa, pengaruh itu terjadi karena keberadaanya siswa dalam masyarakat.Teman bergaul yang baik akan berpengaruh baik terhadap diri siswa, begitu juga sebaliknya, teman bergaul yang jelek pasti mempengaruhi yang bersifat buruk juga. Mass media juga mempengaruhi siswa dalam belajar. Mass media yang baik memberi pengaruh yang baik terhadap siswa dan juga terhadap belajarnya. Jika siswa memanfaatkan internet sebagai temapat belajar maka akan berdanpak baik dan begitu juga sebaliknya.

\section{Hubungan faktor kesulitan belajar kimia dan hasil belajar kimia}

Hasil perhitungan hubungan atau korelasi antara faktor-faktor yang menyebabkan kesulitan belajar dengan hasil belajar kimia siswa didapatkan korelasi yang termasuk kategori rendah. Akantetapi jika dilihat dari hasil uji signifikasinya didapatkan hubungan yang positif dan signifikan. Hal tersebut dapat dilihat dari perbandingan nilai r-hitung 0,357, sedangkan r-tabelnya dengan $\mathrm{N}=130$ pada taraf signifikan $5 \%$ sebesar 0,172 . Hal tersebut menunjukkan harga r-hitung lebih besar dari rtabel, maka dapat diartikan bahwa terdapatnya hubungan yang positif dan signifikan antara faktorfaktor yang menyebabkan kesulitan belajar dengan hasil belajar kimia siswa kelas XII SMAN 1
Narmada selama proses belajar dari rumah. Hasil analisis data menunjukkan bahwa hipotesis tersebut telah terbukti di mana terdapat hubungan yang signifikan antara kedua variable tersebut. Hal ini sejalan dengan penelitian Sari (2019) yang menyatakan terdapat hubungan yang signifikan antara kesulitan belajar dengan hasil belajar siswa yang dipicu oleh beberapa faktor yang mempengaruhi kesulitan belajar. Dapat dikatakan siswa yang mengalami kesulitan belajar akan sulit dalam menerima pembelajaran dan memahami pelajaran.

Adapula harga koefisien determinasi sebesar $12,7 \%$ berpengaruh positif, hal tersebut menunjukkan pada saat proses belajar dari rumah atau bisa juga disebut belajar daring/online semakin rendah kesulitan belajar siswa, maka akan semakin tinggi pula hasil belajar yang didapatkan siswa. Sedangkan nilai $87,3 \%$ merupakan faktor atau variabel lain yang terkait dengan hasil belajar (seperti kebiasan belajar, intelegensi siswa, kematangan, kesiapan dll) yang tidak termasuk dalam faktor-faktor kesulitan belajar pada penelitian ini.

\section{SIMPULAN}

Berdasarkan hasil dan pembahasan penelitian yang didapatkan dalam bab sebelumnya, maka dapat ditarik kesimpulan dari penelitian ini adalah sebagai berikut: (1) Kesulitan belajar kimia siswa pada materi sifat koligatif larutan berada pada kategori rendah $(33,29 \%)$. Tingkat kesulitan belajar yang paling tinggi terdapat pada indikator ke-3 (menghitung tekanan uap larutan elektrolit) pada soal nomor 4 sebesar $71,58 \%$ dengan kategori tinggi. (2) Faktor penyebab kesulitan belajar bagi siswa ditinjau dari faktor internal adalah faktor minat dengan persentase sebesar 69,23\% kategori cukup sulit, dan faktor motivasi dengan persentase sebesar 51,53\% kategori cukup sulit. Secara umum dapat dikatakan masih ada kesulitan belajar dalam diri siswa. (3) Faktor penyebab kesulitan belajar siswa ditinjau dari faktor eksternal meliputi faktor keluarga dengan presentase terbesar 45,39\% kategori cukup sulit dan sulit, faktor sekolah dengan persentase terbesar $42,30 \%$ kategori cukup sulit, faktor lingkungan masyarakat dengan persentase terbesar 49,23\% kategori cukup sulit, dan faktor materi kimia sebesar 60,77\% kategori cukup sulit. (4) Terdapat hubungan yang positif dan signifikan antara faktor kesulitan belajar kimia dengan hasil belajar kimia siswa, yang didasarkan oleh nilai koefisien korelasi sebesar 0,357 dengan kategori rendah. 


\section{DAFTAR PUSTAKA}

Arikunto, Suharsini. 2018. Prosedur Penelitian Suatu Pendekatan Praktek. Jakarta: RinekaCipta.

Aunurrahman. (2013). Belajar dan Pembelajaran. Bandung: Alfabeta.

Azwar, S. 2012. Metode Penelitian. Yogyakarta: Pustaka Belajar.

Basyari, Asyhar. (2013). Hubungan antara Minat dan Prestasi Belajar Sejjarah dengan Kesadaran Sejarah Siswa MAN Yogyakarta III. Skripsi:48.

Cahyati, Nika., Kusumah, Rita. 2020. Peran Orang Tua dalam Menerapkan Pembelajaran di Rumah Saat Pandemi Covid 19. Jurnal Golden Age Universitas Hamzanwadi, Vol. 04 (1): 152-159.

Dinatha, Ngurah Mahendra dan Laksana, Dek Ngurah Laba. 2017. Kesulitan Belajar Siswa Dalam Mata Pelajaran Ipa Terpadu. Jurnal Pendidikan Dasar Nusantara, Volume 2 Nomor 2, Hal: 214 - 223.

Djamarah, Syaiful Bahri. 2010. Psikologi Belajar. Jakarta: Rineka Cipta.

Haris, Mukhtar., Al Idrus, Syarifa Wahidah. 2008. Analisis Kesulitan Belajar Ikatan Kimia Ditinjau Dari Kesalahan Konsep Siswa Kelas X SMA Negeri 3 Mataram. Jurnal Pijar MIPA, Vol. VI No.2, hal: 77-80.

Haris, Mukhtar; Muntari; dan Loka, I Nyoman. 2019. Penerapan Pembelajaran Kooperatif Terpadu NHTdan TSTSdalam Mengatasi Kesulitan Belajar Struktur Atom dan Sistem Periodik Unsur. Jurnal Pijar MIPA, Vol. 14 No.3, ha:123-127.

Prasetyaningtyas, Susi. 2020. Pelaksanaan Belajar Dari Rumah (Bdr) Secara Online Selama Darurat Covid-19 Di Smp N 1 Semin. Jurnal Karya Ilmiah Guru, Vol. 5 No. 1: 86-94.

Ristiyani, Erika dan Bahriah, Evi Sapinatul. 2016. Analisis Kesulitan Belajar Kimia Siswa Di Sman X Kota Tangerang Selatan. Jurnal Penelitian dan Pembelajaran IPA, Vol. 2, No. 1, Hal: 18-29.

Rumansyah dan Irhasyuarna, Y. 2004. Penerapan Metode Latihan Bersturktur Dalam Meningkatkan Pemahaman Siswa Terhadap Konsep Persamaan Kimia. Jurnal Pendidikan dan Kebudayaan, Vol. 8(35): 172.

Sakti, Ela Lucy., Ulianas, Alizar. 2018. Deskripsi Kesulitan Belajar Siswa Sma Pada Materi Stoikiometri. Jurnal Residu, Vol 2 (10): 16-26.
Sari, Indria Ririn., Sumarmin, Ramadhan. 2019. Analisis Hubungan Minat Belajar dan Kesulitan Belajar dengan Hasil Belajar Siswa SMP di Kota Padang. Jurnal Atrium Pendidikan Biologi: 9-16.

Slameto. 2003. Belajar dan Faktor-Faktor yang Mempengaruhinya. Jakarta: Rineka Cipta.

Sugiyono. 2018. Penelitian Pendidikan metode penelitian kuantitatif, kualitatif, dan $R \& D$. Bandung: Alfabeta.

Suryabrata, Sumandi. 2011. Psikologi Pendidikan. Jakarta: PT Rajagrafindo Persada.

Yakina., Kurniati, Tuti., Fadhilah, Raudhatul. 2017. Analisis Kesulitan Belajar Siswa Pada Mata Pelajaran Kimia Kelas X Di SMA Negeri 1 Sungai Ambawang. ArRazi Jurnal Ilmiah, Vol. 5 No. 2, Hal: 288-297. 